Jakub Sawulski*

\title{
Potencjalne ryzyka związane z przystąpieniem do strefy euro - doświadczenia państw Europy Środkowo-Wschodniej
}

\begin{abstract}
Benefits and costs of joining the eurozone-experience of Central and Eastern European countries: This article discusses experience of Central and Eastern European (CEE) countries which have adopted the euro. The emphasis is placed on three phenomena: an increase in inflation, a decline in competitiveness and a greater volatility of the economic growth. As the analysis shows, there was no effect of price increase due to currency conversion in all CEE countries, as well as neither loss of competitiveness nor decrease in foreign trade balance has been proved. However, CEE countries that adopted the euro experienced greater fluctuations of economic growth - both the minimum and maximum GDP growth rate was relatively high in comparison to CEE countries which kept their currencies.
\end{abstract}

\footnotetext{
Słowa kluczowe: strefa euro, inflacja, konkurencyjność, zmienność koniunktury Keywords: eurozone, inflation, competitiveness, growth volatility

* Doktor nauk ekonomicznych, adiunkt w Szkole Głównej Handlowej w Warszawie, ekspert ds. finansów publicznych BAS • e-mail: jsawul@sgh.waw.pl • https://orcid.org/oooo-0002-8777-2710
}

\section{Wstęp}

Przyjęcie przez Polskę waluty euro powinno zostać poprzedzone wyczerpującą analizą potencjalnych pozytywnych i negatywnych skutków takiego kroku. Bez wątpienia jednym z najważniejszych elementów takiej analizy powinien być przegląd doświadczeń wynikających z przyjęcia wspólnej europejskiej waluty w innych państwach Europy Środkowo-Wschodniej, a więc państwach podobnych do Polski pod względem obecnego poziomu rozwoju oraz historii gospodarczej ostatnich kilkudziesięciu lat.

Celem niniejszego artykułu jest ocena wybranych konsekwencji przyjęcia waluty euro w pięciu państwach Europy Środkowo-Wschodniej, które w 2004 r. 
wspólnie z Polską wstępowały do Unii Europejskiej, a następnie przyjęły także wspólną europejską walutę. Są to (w nawiasie rok przystąpienia do strefy euro): Słowenia (2007), Słowacja (2009), Estonia (2011), Łotwa (2014) oraz Litwa (2015). W szczególności zbadano zmiany we: wskaźnikach cen, wskaźnikach konkurencyjności oraz poziomie produktu krajowego brutto. Poddano tym samym weryfikacji trzy zjawiska, w literaturze przedstawiane jako potencjalne negatywne skutki przyjęcia wspólnej waluty: wzrost inflacji, spadek konkurencyjności oraz większą zmienność koniunktury. W artykule zbadano też hipotezę, zgodnie z którą przystąpienie do strefy euro nie wiązało się z wyższym wzrostem cen, spadkiem konkurencyjności oraz większą zmiennością koniunktury $\mathrm{w}$ analizowanych państwach.

Autor wykorzystuje badania przedstawione w literaturze przedmiotu, wnioski płynące z badań prowadzonych przez Eurostat i Europejski Bank Centralny oraz dane statystyczne zawarte w bazie Eurostatu. Zakres czasowy analizy obejmuje lata 2004-2018. W części pierwszej artykułu przedstawiono przebieg przygotowań państw Europy Środkowo-Wschodniej do przyjęcia waluty euro. Następnie kolejno przeanalizowano zmiany występujące po wprowadzeniu euro w tych państwach w trzech obszarach: cen, konkurencyjności oraz koniunktury. Artykuł kończy się podsumowaniem, w którym zaprezentowano najważniejsze wnioski z przeprowadzonej analizy.

\section{Proces przygotowania państw Europy Środkowo-Wschodniej do przyjęcia waluty euro}

Wejście danego kraju do strefy euro poprzedzone jest co najmniej kilkuletnim procesem przygotowań. Najważniejszym ich elementem jest konieczność spełnienia gospodarczych oraz regulacyjnych kryteriów konwergencji. Kryteria te mają za zadanie zagwarantować, że przystąpienie danego państwa do strefy euro nie narazi jego samego ani innych państw strefy na ryzyko ekonomiczne. Kryteria gospodarcze dotyczą czterech obszarów:

- stabilnego kursu walutowego - co najmniej dwuletnie uczestnictwo w systemie ERM II, w trakcie którego waluta nie może wykazywać znaczących odchyleń od ustalonego kursu,

- stabilnych cen - stopa inflacji nie może przekraczać średniej inflacji w trzech najbardziej stabilnych cenowo państwach członkowskich UE powiększonej o 1,5 pkt proc.,

- stabilnych długoterminowych stóp procentowych - średnia nominalna długoterminowa stopa procentowa nie może przekraczać więcej niż o 2 pkt proc. stopy procentowej trzech państw członkowskich UE o najbardziej stabilnych cenach,

- długotrwałej równowagi finansów publicznych - deficyt finansów publicznych nie może przekraczać 3\% PKB, a dług publiczny 60\% PKB. 
Oprócz tego pod uwagę brane są także: poziom integracji rynków, sytuacja i rozwój równowagi płatności bieżących oraz ocena rozwoju jednostkowych kosztów pracy i innych wskaźników cen. Z kolei kryteria regulacyjne obejmują konieczność dostosowania przepisów do wymogów traktatowych, w tym zagwarantowania niezależności banku centralnego i odpowiednich zmian w jego statucie ${ }^{1}$.

Po rozszerzeniu Unii Europejskiej w 2004 r. do strefy euro przystąpiło pięć państw Europy Środkowo-Wschodniej (dalej: państwa EŚW), kolejno: Słowenia, Słowacja, Estonia, Łotwa i Litwa. Trzy spośród nich - Estonia, Litwa i Łotwa utrzymywały systemy kursu stałego od początku lat 90., a więc na długo przed przyjęciem wspólnej europejskiej waluty (tabela 1). Łotwa początkowo dostosowywała kurs waluty na zasadzie umownego kursu stałego do kursu jednostek $\mathrm{SDR}^{2}$, a Estonia i Litwa poprzez system zarządu walutą (izbę walutową) do, odpowiednio, marki niemieckiej oraz amerykańskiego dolara. Następnie wszystkie te państwa powiązały swoje waluty z euro - Estonia i Litwa od 2002 r., a Łotwa od 2005 r. Z kolei Słowenia do 2002 r. stosowała kurs płynny, w 2003 r. kurs stały wobec euro w przedziale wahań, a od 2004 r. przystąpiła do systemu ERM II. Wyjątkiem w tym gronie jest Słowacja, która jako jedyna aż do momentu wejścia do systemu ERM II zachowywała kurs płynny. W przypadku słowackiej korony i słoweńskiego talara włączenie do mechanizmu ERM II wymagało zmiany systemów kursowych. Kraje te określiły oficjalne kursy centralne swoich walut w stosunku do euro i zobowiązały się do stabilizacji kursów rynkowych w przedziale wahań $\pm 15 \%$. Wobec korony słowackiej aprecjacja w związku z oczekiwaniami, że kraj ten wprowadzi euro, była jednak na tyle silna, że w maju $2007 \mathrm{r}$. dokonano rewaluacji kursu centralnego o $8,5 \%{ }^{3}$.

Niespełnianie części kryteriów konwergencji opóźniło moment przyjęcia euro w niektórych państwach EŚW. Dotyczy to zwłaszcza państw bałtyckich: Estonii, Litwy i Łotwy. Kraje te - ze względu na powiązanie własnych walut z euro - dążyły do przyjęcia wspólnej europejskiej waluty od momentu wejścia do Unii Europejskiej. Wydarzenie to zostało jednak przesunięte w czasie ze względu na globalny kryzys finansowy rozpoczęty w 2008 r., który silnie wpłynął na pogorszenie salda finansów publicznych w tych państwach. Deficyt wyższy niż wymagane w kryteriach konwergencji 3\% PKB wystąpił w latach

1 Traktat o funkcjonowaniu Unii Europejskiej, Dz.Urz. UE C 326/47 z 26 października 2012 r., art. 140.

2 Międzynarodowa jednostka walutowa (tzw. specjalne prawa ciągnienia) o charakterze pieniądza bezgotówkowego, emitowana przez Międzynarodowy Fundusz Walutowy.

${ }^{3}$ K. Twarowska, Ocena polityki kursu walutowego wybranych krajów Europy Środkowo-Wschodniej $w$ aspekcie optymalizacji strategii przyjęcia euro, „Finanse, Rynki Finansowe, Ubezpieczenia" 2016, nr 3(81), s. 237-251; M. Jurek, Systemy kursów walutowych krajów Europy Środkowo-Wschodniej oraz zmienność kursów ich walut względem euro, „Ekonomista” 2013, nr 2, s. 221-245. 
Tabela 1. Charakterystyka procesu konwergencji w wybranych państwach Europy Środkowo-Wschodniej

\begin{tabular}{|c|c|c|c|c|c|c|c|}
\hline \multicolumn{2}{|c|}{ Wyszczególnienie } & Słowenia & Słowacja & Estonia & Łotwa & Litwa & Polska \\
\hline \multicolumn{2}{|c|}{$\begin{array}{l}\text { System kursowy } \\
\text { przed przystąpieniem } \\
\text { do ERM II }\end{array}$} & $\begin{array}{l}\text { Kurs stały } \\
\text { w przedzia- } \\
\text { le wahań } \\
\text { (od } 2003 \text { r.) }\end{array}$ & $\begin{array}{l}\text { Kurs płynny } \\
\text { (od 1998 r.) }\end{array}$ & $\begin{array}{c}\text { Izba } \\
\text { walutowa } \\
\text { (od } 1992 \text { r.) }\end{array}$ & $\begin{array}{l}\text { Umowny } \\
\text { kurs stały } \\
\text { (od } 1994 \text { r.) }\end{array}$ & $\begin{array}{c}\text { Izba } \\
\text { walutowa } \\
\text { (od 1994 r.) }\end{array}$ & $\begin{array}{c}\text { Kurs } \\
\text { całkowicie } \\
\text { płynny }\end{array}$ \\
\hline \multicolumn{2}{|c|}{$\begin{array}{l}\text { Rok przystąpienia } \\
\text { do ERM II }\end{array}$} & 2004 & 2005 & 2004 & 2005 & 2004 & $\mathrm{n} / \mathrm{a}$ \\
\hline \multicolumn{2}{|c|}{ Rok przyjęcia euro } & 2007 & 2009 & 2011 & 2014 & 2015 & $\mathrm{n} / \mathrm{a}$ \\
\hline \multirow{5}{*}{ 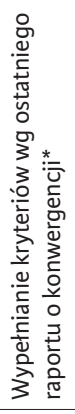 } & $\begin{array}{l}\text { Data ostatniego } \\
\text { raportu } \\
\text { o konwergencji } \\
\end{array}$ & maj 2006 & maj 2008 & maj 2010 & $\begin{array}{l}\text { czerwiec } \\
2013\end{array}$ & $\begin{array}{c}\text { czerwiec } \\
2014\end{array}$ & maj 2018 \\
\hline & Inflacja HICP (\%) & $2,3(2,6)$ & $2,2(3,2)$ & $-0,7(1,0)$ & $1,3(2,7)$ & $0,6(1,7)$ & $1,4(1,9)$ \\
\hline & $\begin{array}{l}\text { Długoterminowe } \\
\text { stopy } \\
\text { procentowe (\%) }\end{array}$ & $3,8(5,9)$ & $4,5(6,5)$ & brak $^{* *}$ & $3,8(5,5)$ & $3,6(6,2)$ & $3,3(3,2)$ \\
\hline & $\begin{array}{l}\text { Saldo finansów } \\
\text { publicznych } \\
(\% \text { PKB) }\end{array}$ & $-1,9(-3,0)$ & $-2,0(-3,0)$ & $-2,4(-3,0)$ & $-1,2(-3,0)$ & $-2,1(-3,0)$ & $-1,4(-3,0)$ \\
\hline & $\begin{array}{l}\text { Dług publiczny } \\
\text { (\%) PKB) }\end{array}$ & $29,9(60)$ & $29,2(60)$ & $9,6(60)$ & $43,2(60)$ & $41,8(60)$ & $49,6(60)$ \\
\hline
\end{tabular}

* W nawiasach podano wartość referencyjną (maksymalną dopuszczalną). Dla kryteriów fiskalnych dane przedstawiają prognozę Komisji Europejskiej na rok publikacji raportu o konwergencji. Dla kryteriów cen i stóp procentowych dane za 12 miesięcy poprzedzających datę publikacji raportu.

** Brak danych o długoterminowych stopach procentowych w Estonii, gdyż kraj ten charakteryzował się zbyt słabo rozwiniętym rynkiem długoterminowych papierów wartościowych denominowanych w krajowej walucie. Źródło: na podstawie raportów o konwergencji Europejskiego Banku Centralnego oraz K. Twarowska, Ocena polityki kursu walutowego wybranych krajów Europy Środkowo-Wschodniej w aspekcie optymalizacji strategii przyjęcia euro, „Finanse, Rynki Finansowe, Ubezpieczenia” 2016, nr 3(81), s. 237-251.

2008-2012 na Litwie oraz w latach 2008-2011 na Łotwie. Blisko przekroczenia kryterium deficytu była także Estonia - w 2008 i 2009 r. ${ }^{4}$. Państwa EŚW miały też trudności ze spełnianiem kryterium odpowiednio niskiej inflacji. Dotyczy to zwłaszcza okresu szybkiego rozwoju gospodarczego przed kryzysem finansowym. W 2008 r. roczny wzrost cen w każdym z państw bałtyckich przekraczał $10 \%{ }^{5}$. Z kolei na Słowacji wskaźnik ten obniżono z 4,3\% w 2006 r. do 2,2\% $\mathrm{w}$ momencie publikacji ostatniego raportu przed wejściem tego kraju do strefy euro, czyli w maju 2008 r.

Ostatecznie państwa EŚW spełniały wszystkie kryteria konwergencji w okresie poprzedzającym wejście do strefy euro (tabela 1). Konieczność podjęcia wysiłku w celu osiągnięcia wymaganych kryteriami konwergencji wskaźników gospodarczych uznaje się za jedną z pozytywnych stron dążenia do przyjęcia

${ }^{4}$ Na podstawie danych Eurostatu, https://ec.europa.eu/eurostat/data/database [dostęp: 12 maja 2019 r.].

5 Ibidem. 
wspólnej europejskiej waluty ${ }^{6}$. W przypadku polskiej gospodarki tego typu dodatkowe obostrzenia nie wydają się jednak konieczne. Według raportu o konwergencji z maja 2018 r. Polska spełniała oba kryteria fiskalne oraz kryterium poziomu cen. Co do kryterium długoterminowej stopy procentowej to odstępstwo Polski od wartości referencyjnej było w maju 2018 r. minimalne - wyniosło 0,1 pkt proc. Warto jednak zauważyć, że wszystkie państwa EŚW, które przyjęły euro, wchodziły do strefy z wyraźnie niższym poziomem długu publicznego w relacji do PKB niż Polska. Dotyczy to zwłaszcza Estonii, Słowacji i Słowenii, a w mniejszym stopniu także Litwy i Łotwy.

\section{Przyjęcie euro a zmiany poziomu cen}

Wzrost cen w wyniku konwersji waluty jest jednym z najczęściej wskazywanych potencjalnych zagrożeń związanych $\mathrm{z}$ przyjęciem euro w debacie publicznej. Obawy związane z możliwym wzrostem cen są także silnie zakorzenione w polskim społeczeństwie. Według badania przeprowadzonego na zlecenie Komisji Europejskiej w kwietniu 2018 r. 71\% Polaków uważa, że wprowadzenie euro doprowadzi do wzrostu cen w kraju. To drugi najwyższy odsetek wśród wszystkich państw EŚW nienależących do strefy euro (udział takich odpowiedzi waha się od 74\% w Chorwacji do 51\% na Węgrzech). 70\% respondentów w Polsce uważa też, że moment konwersji waluty wiązałby się z nadużyciami w ustalaniu cen ${ }^{7}$.

W momencie przystąpienia do strefy euro ceny wyrażone w krajowej walucie są przeliczane na euro według ustalonego kursu konwersji. Jest to operacja techniczna, która nie powinna mieć istotnego wpływu na wzrost cen w średnim i długim okresie (może nawet inflację obniżać - przez mniejsze koszty transakcyjne wymiany walut oraz mniejsze ryzyko kursowe). Istnieją jednak podstawy teoretyczne, które pozwalają sądzić, że efekt wzrostu cen może wystąpić w krótkim okresie. Może to wynikać z trzech czynników:

- zaokrąglanie cen w górę w trakcie przeliczania po kursie konwersji,

- przerzucanie kosztów konwersji (tzw. koszty zmiany menu) na konsumentów,

- wykorzystanie konwersji waluty do zwiększenia marży przez przedsiębiorstwa o silnej pozycji rynkowej (działające w warunkach niskiej konkurencji).

${ }^{6}$ Zob. T. Sporek, Perspektywy i konsekwencje wprowadzenia euro w Polsce - bilans korzyści i kosztów, „Zeszyty Naukowe Uniwersytetu Ekonomicznego w Katowicach” 2015, nr 228, s. 7-21.

7 Introduction of the euro in the Member States that have not yet adopted the common currency, European Commission, Flash Eurobarometer 465, Brussels 2018, s. 33-35.

8 A. Pufnik, Effects of the Adoption of the Euro on Consumer Prices and Inflation Perceptions: An Overview of Experiences and Assessment of the Possible Impact in Croatia, Croatian National Bank, Zagreb 2017, s. 1. 
Liczne badania na ten temat wskazują jednak, że wpływ konwersji narodowych walut na euro na zmiany cen konsumenckich był niewielki i jednorazowy. Nieznacznie większy wzrost cen w wyniku konwersji waluty występował dla wąskiej grupy produktów, głównie w sektorze usług (np. w restauracjach i kawiarniach $)^{9}$.

Analiza zmian cen w państwach EŚW, które przyjęły euro, także nie potwierdza istnienia efektu wzrostu cen w związku z konwersją waluty (wykres 1).

Wykres 1. Miesięczna inflacja w państwach EŚW oraz jej różnica wobec miesięcznej inflacji w strefie euro w roku poprzedzającym przyjęcie euro oraz w roku przyjęcia euro

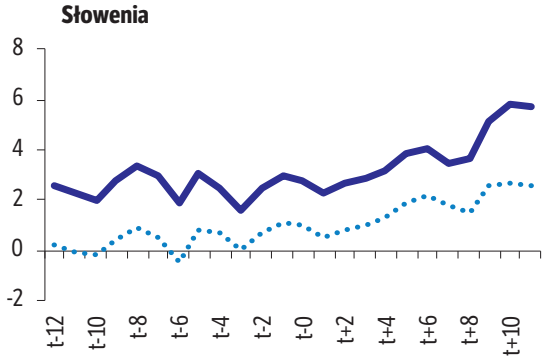

Słowacja
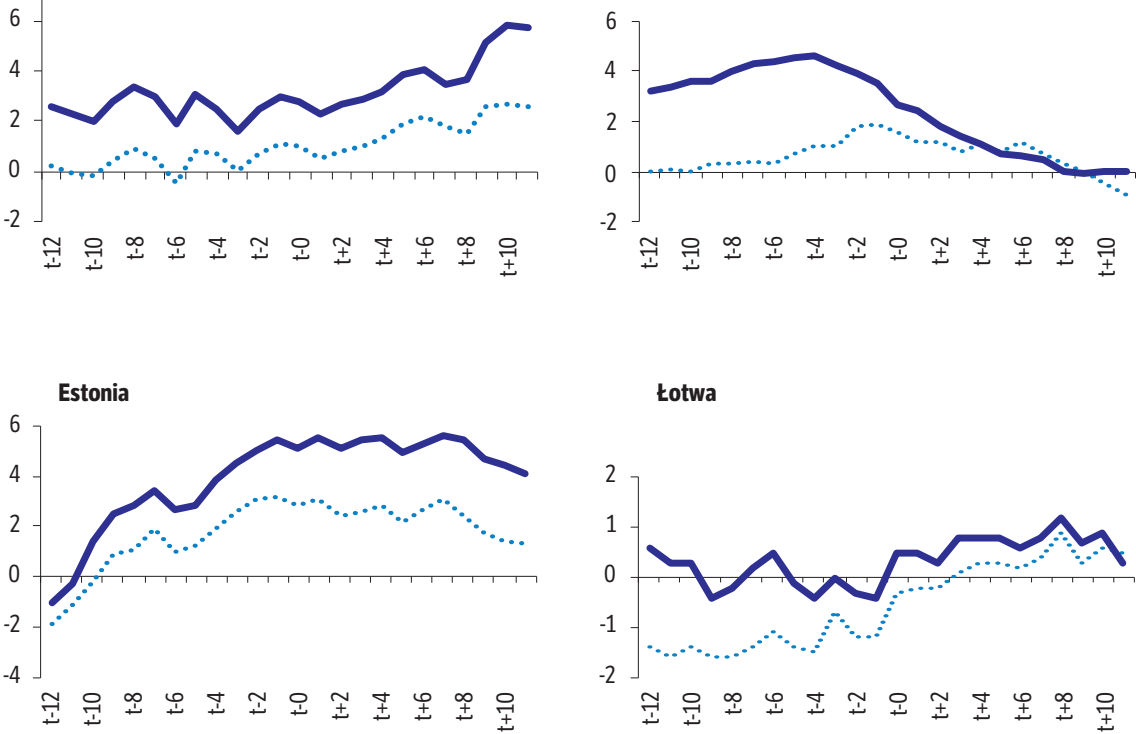

Łotwa
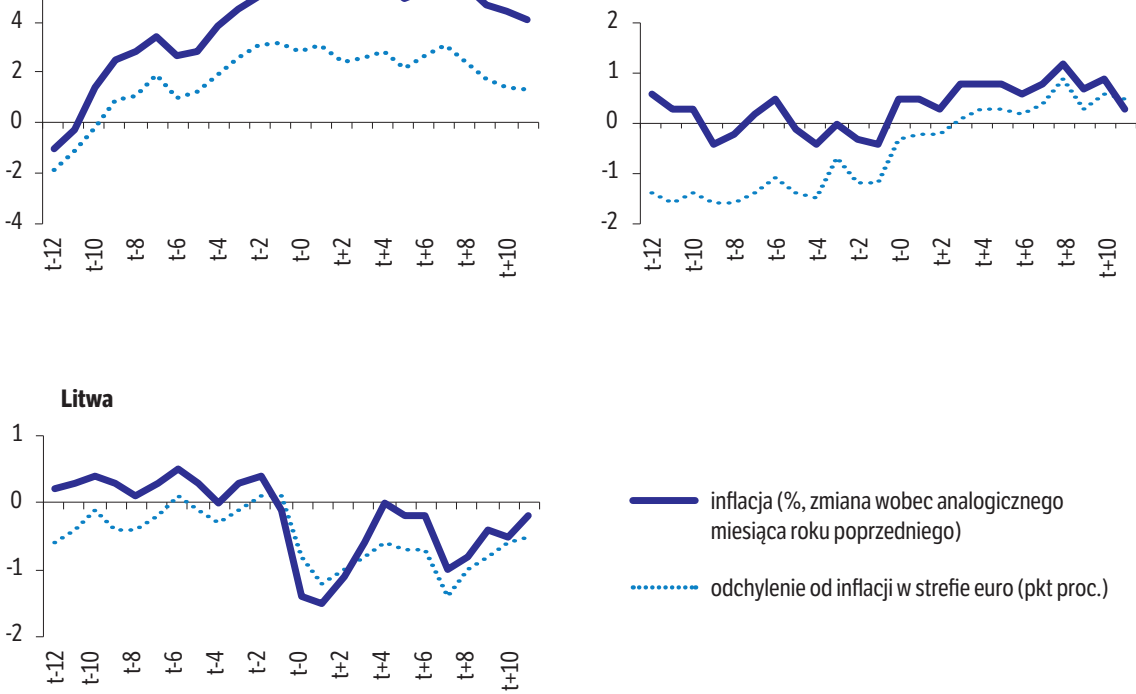

inflacja (\%, zmiana wobec analogicznego odchylenie od inflacji w strefie euro (pkt proc.)

Uwagi: t-o oznacza miesiąc przyjęcia euro.

Źródło: na podstawie danych Eurostatu, https://ec.europa.eu/eurostat/data/database.

9 Ibidem, s. 1-3. 
Jednym państwem, w którym nastąpił istotny wzrost inflacji oraz wzrost różnicy wobec inflacji obserwowanej w strefie euro, była Słowenia. W tym kraju w pierwszym roku po wprowadzeniu euro wskaźnik miesięcznej inflacji wzrósł o ok. 3 pkt proc., a różnica wobec inflacji w strefie euro o blisko 2 pkt proc. Podobne zjawisko, lecz w znacznie mniejszej skali (wzrost inflacji i różnicy wobec inflacji w strefie euro o mniej niż 1 pkt proc.), wystąpiło także na Łotwie. W Estonii w pierwszych miesiącach po wprowadzeniu euro wskaźnik zmian cen był wysoki - wynosił ok. 5\%, a więc o 2-3 pkt proc. więcej niż w strefie euro. Jego dynamiczny wzrost nastąpił jednak nie po przyjęciu wspólnej europejskiej waluty, a w roku poprzedzającym to wydarzenie. Występowaniu efektu wzrostu cen w wyniku konwersji waluty przeczą przede wszystkim przypadki Słowacji i Litwy. W obu tych państwach w pierwszym roku po wprowadzeniu euro nastąpił spadek zarówno wskaźnika zmian cen, jak i różnicy wobec wskaźnika zmian cen w strefie euro. Nie zaobserwowano także znaczącej różnicy między stopą inflacji w tych krajach a stopą inflacji w strefie euro w roku poprzedzającym przyjęcie wspólnej waluty.

Potencjalne efekty cenowe zaokrągleń w wyniku wprowadzenia euro do obiegu były przedmiotem badań również w Polsce. Według symulacji efekty cenowe zaokrągleń zależą $\mathrm{w}$ dużym stopniu od ustalenia odpowiedniego kursu konwersji. Możliwy wzrost cen wyniósł od 0,04\% do 2,56\% w zależności od przyjętego scenariusza. Za najbardziej podatne na zaokrąglenia cen w górę uznano produkty o niskich cenach jednostkowych, w tym towary najczęściej kupowane ${ }^{10}$. Warto jednak podkreślić, że państwa mają możliwość zastosowania określonych instrumentów, które mogą zapobiegać przejściowemu wzrostowi zarówno cen, jak i zaburzeniom w postrzeganiu inflacji przez konsumentów. Wśród nich wymienia się m.in.: obowiązek publikowania cen w obu walutach przez określony czas, promowanie uczciwego ustalania cen przez korporacje oraz prowadzenie kampanii informacyjnych ${ }^{11}$.

O ile efekt wyraźnego wzrostu cen w wyniku konwersji waluty nie znajduje potwierdzenia $w$ literaturze oraz danych empirycznych, o tyle badania wskazują, że konwersja przyczynia się do wzrostu luki między percepcją inflacji wśród konsumentów a jej faktycznym poziomem. W państwach, które przyjęły euro, znacznie wzrósł odsetek konsumentów, którzy deklarowali, że ceny istotnie wzrosły w ostatnim roku. To z kolei przekładało się na rosnącą lukę między tym, jaką stopę wzrostu cen wskazywali konsumenci w ankietach, a ile faktycznie wynosił wskaźnik inflacji. Zjawisko to można było zaobserwować m.in. w krajach EŚW - wyraźnego wzrostu luki między percepcją inflacji a jej faktycznym poziomem po wprowadzeniu euro doświadczyły Słowenia,

${ }_{10}$ M. Rozkrut, J.T. Jakubik, K. Konopczak, Efekty zaokragleń cen w Polsce po wprowadzeniu euro do obiegu gotówkowego, „Bank i Kredyt” 2009, nr 40(2), s. 61-96.

11 A. Pufnik, Effects of the Adoption, op. cit., s. 1. 
Estonia i Litwa. Zjawisko to nie wystąpiło na Litwie, a w Słowacji miało charakter odwrotny (odczuwana przez konsumentów stopa inflacji spadła, a luka wobec danych rzeczywistych była ujemna). Co jednak istotne, dotychczasowe doświadczenia wskazują, że wzrost odczuwanej inflacji jest przejściowy i nie ma odzwierciedlenia we wzroście oczekiwań inflacyjnych, a tym samym nie wywołuje także wyższych żądań płacowych oraz spirali inflacyjnej ${ }^{12}$.

\section{Przyjęcie euro a konkurencyjność}

Państwa znajdujące się na ścieżce realnej konwergencji cechują się wyższą niż w państwach najbogatszych dynamiką wynagrodzeń, a co za tym idzie także wyższą inflacją. Sytuacja ta ma miejsce m.in. w państwach Europy Środkowo-Wschodniej (w porównaniu z państwami tzw. starej piętnastki UE). Zjawisko to nazywa się w literaturze efektem Balassy-Samuelsona ${ }^{13}$.

Problem utraty międzynarodowej konkurencyjności przez dane państwo pojawia się, gdy płace w gospodarce stają się zbyt wysokie w stosunku do produktywności w sektorze wytwarzającym dobra, które podlegają wymianie międzynarodowej. Skutkiem jest wypieranie produkowanych w kraju dóbr przez dobra produkowane za granicą (zarówno na rynku krajowym, jak i rynkach zagranicznych). Problem ten może być szczególnie istotny w przypadku państw konwergujących, które zdecydowały się na przyjęcie wspólnej europejskiej waluty. Kraje te nie mają bowiem możliwości poprawy konkurencyjności międzynarodowej przez automatyczne dostosowanie kursu walutowego, co może mieć szczególne znaczenie w okresach kryzysów gospodarczych. Brak płynnego kursu wobec istotnych partnerów gospodarczych zmusza wówczas kraje nieposiadające własnej waluty do tzw. wewnętrznej dewaluacji, a więc długotrwałego spadku cen i płac ${ }^{14}$. Jako przykład pozytywnych konsekwencji deprecjacji waluty dla złagodzenia skutków kryzysu podaje się sytuację Polski w roku 2008 i 2009, gdy złoty polski osłabił się o ok. $30 \%$, co przyczyniło się do poprawy salda handlu zagranicznego i utrzymania wzrostu PKB. Z kolei wobec państw połu-

12 Ibidem, s. 3-5.

13 A. Czerniak, A. Smoleńska, Polska bez euro. Bilans kosztów i korzyści, Polityka Insight, 2019, https://www.politykainsight.pl/en/_resource/multimedium/20164985, s. 32-35. Zob. szerzej: J. Boratyński, J. Borowski, A. Czerniak, D. Rosati, Sectoral Decomposition of the Balassa-Samuelson Effect in CEE Countries: A CGE Analysis, „Eastern European Economics” 2019, No 57(2), https://doi.org/10.1080/00128775.2018.1552521, s. 153-177; K. Konopczak, A. Welfe, Convergence-driven inflation and the channels of its absorption, "Journal of Policy Modeling” 2017, No 39, s. 1019-1034.

14 P. Arestis, M. Sawyer, The Design Faults of the Economic and Monetary Union, „Journal of Contemporary European Studies" 2011, No 19(1), https://doi.org/10.1080/14782804.20 11.554191, s. 21-32; S. Kawalec, E. Pytlarczyk, Paradoks euro. Jak wyjść z pułapki wspólnej waluty?, Poltext, Warszawa 2016, s. 39 i 40. 
dnia Europy - Grecji, Hiszpanii, Portugalii i Włoch - szacuje się, że odzyskanie konkurencyjności w okresie globalnego kryzysu gospodarczego wymagałoby obniżenia płac w tych krajach o $10-30 \%^{15}$.

Konkurencyjność międzynarodowa gospodarki zależy przede wszystkim od relacji między produktywnością pracy a poziomem płac (w szczególności w sektorach wytwarzających dobra podlegające wymianie handlowej). Wartości wynagrodzeń na jednostkę wytwarzanego produktu pokazują jednostkowe koszty pracy. Na wykresie 2 przedstawiono kształtowanie się tego wskaźnika od 2004 do 2018 r. w pięciu państwach EŚW, które przyjęły euro po 2004 r., czterech państwach EŚW, które mają własne waluty i stosują różne odmiany kursu płynnego - w Czechach ${ }^{16}$, Polsce, Rumunii i na Węgrzech, oraz w największej gospodarce UE, będącej jednocześnie największym partnerem handlowym dla większości państw EŚW - w Niemczech.

Wykres 2. Jednostkowe koszty pracy w wybranych państwach Europy Środkowo-Wschodniej oraz w Niemczech w latach 2004-2018

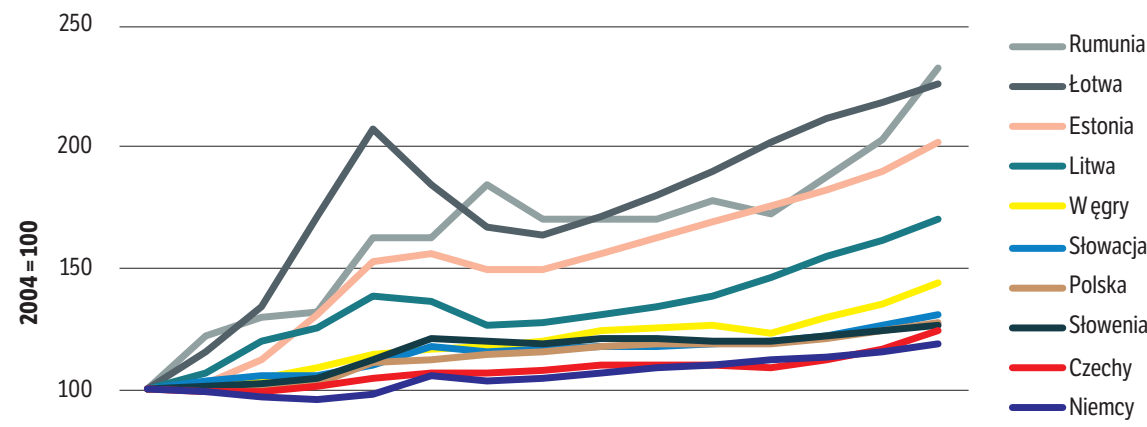

50

200420052006200720082009201020112012201320142015201620172018

Źródło: jak pod wykresem 1.

We wszystkich analizowanych państwach EŚW nastąpiło pogorszenie ich konkurencyjności względem Niemiec w badanym okresie, tzn. wzrost jednostkowych kosztów pracy był wyższy niż w tym kraju. Państwa EŚW można podzielić jednak na trzy grupy: kraje, w których nastąpił szybki - ponaddwukrotny - wzrost jednostkowych kosztów pracy - Estonia, Łotwa i Rumunia; kraje, w których wzrost jednostkowych kosztów pracy był umiarkowany - Litwa

15 Ibidem, s. 43.

${ }^{16}$ Czechy od 2013 r. stosują system stabilizowanego kursu walutowego, zob. K. Twarowska, Ocena polityki, op. cit., s. 242. 
Wykres 3. Saldo handlu zagranicznego w państwach Europy Środkowo-Wschodniej, które przyjęły euro, w latach 2004-2018

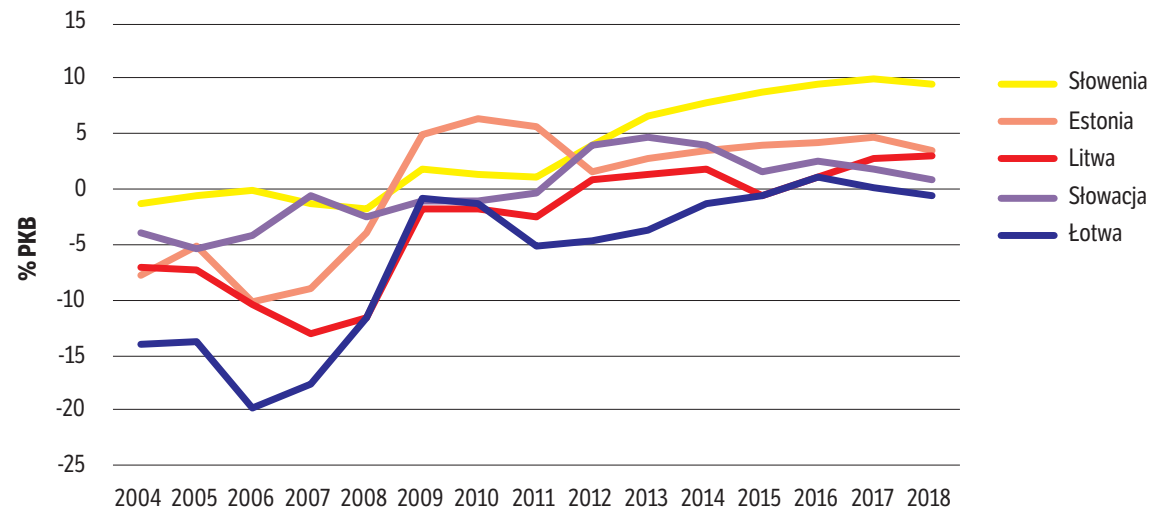

Źródło: jak pod wykresem 1.

i Węgry; oraz kraje, w których wzrost jednostkowych kosztów pracy w badanym okresie w niewielkim stopniu przewyższał wzrost obserwowany w Niemczech Czechy, Polska, Słowacja i Słowenia. Warto zauważyć, że w każdej z tych grup znajdują się zarówno kraje, które w badanych latach stosowały powiązanie kursu własnej waluty z kursem euro i następnie przyjęły wspólną europejską walutę, jak i kraje, które stosowały kurs płynny. Hipoteza, że przyjęcie euro (lub sztywne powiązanie waluty z euro) w długim okresie prowadzi do szybszego spadku konkurencyjności gospodarki niż w innych państwach konwergujących nie znajduje więc potwierdzenia w danych statystycznych.

Państwa EŚW, które przyjęły walutę euro, nie odnotowały także pogorszenia bilansu handlu zagranicznego. Wręcz przeciwnie, w roku 2004 oraz 2005, a więc w momencie, gdy kraje te wchodziły do systemu ERM II, wszystkie miały deficyt w handlu dobrami i usługami (wykres 3). Między rokiem 2004 a 2018 saldo to systematycznie się jednak poprawiało. W 2018 r. niewielki deficyt wystąpił już tylko na Łotwie, a pozostałe cztery kraje - Estonia, Litwa, Słowacja i Słowenia odnotowały nadwyżkę ${ }^{17}$.

\section{Przyjęcie euro a zmienność PKB}

Opisany wyżej brak automatycznych dostosowań kursu walutowego do bieżącej sytuacji gospodarczej w państwach nieposiadających własnej waluty może prowadzić tam do większej zmienności PKB. Większą zmienność PKB może także

17 Między rokiem 2004 a 2018 poprawa salda handlu zagranicznego nastąpiła także w innych analizowanych państwach EŚW - w Czechach, Polsce, Rumunii i na Węgrzech. 
potęgować brak autonomicznej polityki w zakresie ustalania wysokości stóp procentowych. Polityka pieniężna Europejskiego Banku Centralnego jest bowiem ukierunkowana na całą strefę euro, a więc nie uwzględnia specyfiki i potrzeb pojedynczych państw. W literaturze wielokrotnie wskazywano, że taka sama stopa procentowa dla kilkunastu państw strefy euro jest nieoptymalna - nawet jeśli państwa należące do strefy charakteryzują się umiarkowaną synchronizacją cyklu koniunkturalnego, trudno oczekiwać, że w każdym momencie tego cyklu jedna stopa procentowa będzie odpowiednia dla każdego z państw należących do strefy ${ }^{18}$. W przypadku państw EŚW, które przyjęły wspólną europejską walutę, stosunkowo niskie stopy procentowe $\mathrm{w}$ strefie euro mogą z jednej strony prowadzić do przegrzewania gospodarki i powstawania baniek spekulacyjnych w okresach dobrej koniunktury, a z drugiej strony do większych spadków PKB w okresach dekoniunktury.

Cytowani wcześniej A. Czerniak i A. Smoleńska podkreślają jednak, że należy odróżnić wpływ posiadania własnej waluty na możliwość stabilizowania wzrostu gospodarczego od wpływu na trwałe zwiększenie potencjału gospodarczego. Nieprzyjęcie euro oznacza większe możliwości reagowania na sytuacje kryzysowe, ale także gorsze warunki gospodarowania w okresach boomu aprecjację waluty czy relatywnie wysokie stopy procentowe. W długim okresie wpływ przyjęcia wspólnej waluty powinien ujawniać się przede wszystkim w większej amplitudzie wahań koniunktury - szybszym wzroście gospodarczym w okresach dobrej koniunktury oraz większej skali spadku PKB w okresach dekoniunktury ${ }^{19}$.

Porównanie stóp wzrostu PKB w państwach EŚW, które przyjęły euro, oraz w wybranych państwach EŚW, które mają własną walutę, potwierdza obserwacje przedstawione $\mathrm{w}$ dwóch poprzednich akapitach. W latach 2004-2018 amplituda stóp wzrostu PKB była większa w państwach, które przyjęły euro (a wcześniej przystąpiły do mechanizmu ERM II), niż w państwach, które mają własne waluty (wykres 4). Dotyczy to zwłaszcza państw bałtyckich - Estonii, Litwy i Łotwy. W tych państwach odnotowywano ok. 10\% stopy wzrostu w latach poprzedzających globalny kryzys gospodarczy. W 2009 r. państwa te zanotowały z kolei blisko $15 \%$ spadek rocznego PKB. Stosunkowo duża rozpiętość między minimalną i maksymalną stopą wzrostu PKB w badanym okresie - ok.

18 Zob. C. Moons, A. Van Poeck, Does one size fit all? A Taylor-rule based analysis of monetary policy for current and future EMU members, „Applied Economics” 2008, No 40(2), https://doi.org/10.1080/00036840600749763, s. 193-199; D. Furceri, G. Karras, Business-cycle synchronization in the EMU, „Applied Economics” 2008, No 40(12), https://doi. org/10.1080/00036840600843954, s. 1491-1501; D. Gros, Macroeconomic Imbalances in the Euro Area: Symptom or cause of the crisis?, „CEPS Policy Brief” 2012, No. 266; R. Kata i in., Strefa euro: między sceptycyzmem a realizmem, Wydawnictwo CeDeWu, Warszawa 2015, s. 62 .

19 A. Czerniak, A. Smoleńska, Polska bez euro, op. cit., s. 31. 
15 pkt proc. - wystąpiła także na Słowacji i w Słowenii (państwa, które przyjęły euro) oraz w Rumunii (państwo posiadające własną walutę). W grupie analizowanych krajów trzy o najniższej amplitudzie wahań stopy wzrostu PKB to państwa, które nie przystąpily do strefy euro - Czechy, Węgry oraz Polska. Warto zauważyć, że średnia stopa wzrostu w badanym okresie była stosunkowo wysoka zarówno w krajach, które przyjęły euro (np. na Słowacji), jak i w krajach, które mają własną walutę (np. w Polsce i Rumunii). Z kolei najniższe stopy wzrostu odnotowały będąca $\mathrm{w}$ strefie euro Słowenia i znajdujące się poza strefą euro Węgry.

\section{Wykres 4. Minimalna, średnia i maksymalna stopa rocznego wzrostu PKB w wybranych państwach Europy Środkowo-Wschodniej w latach 2004-2018}

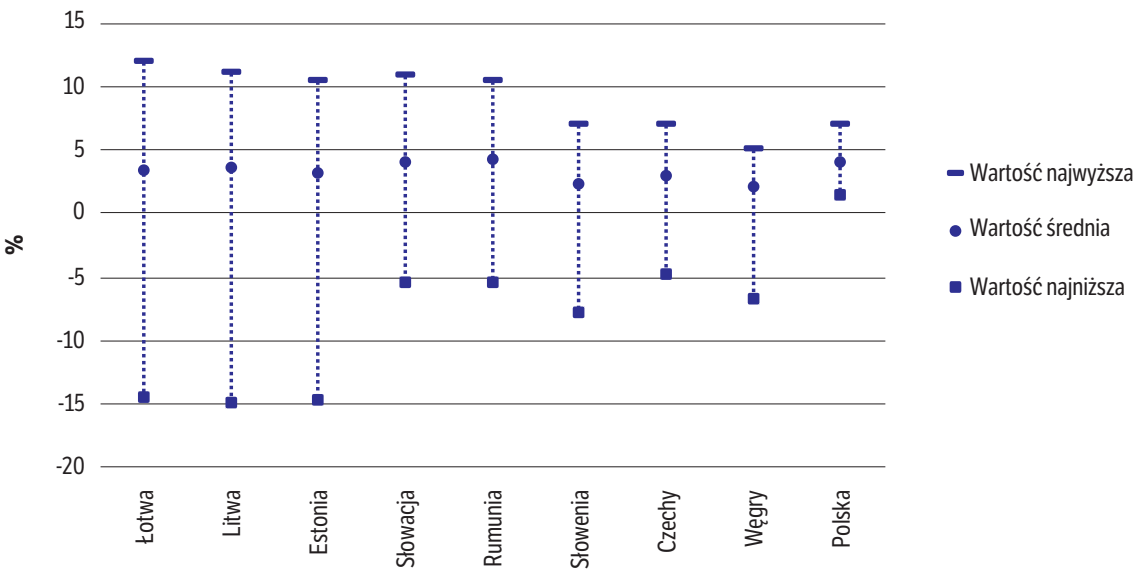

Źródło: jak pod wykresem 1.

Polska na tle analizowanych państw charakteryzowała się najniższą rozpiętością między minimalną i maksymalną stopą wzrostu w badanym okresie. Można podejrzewać, że w przypadku przyjęcia euro tuż po przystąpieniu Polski do UE, rozpiętość ta byłaby większa. Tego rodzaju scenariusz kontrfaktyczny zbudowali M. Brzoza-Brzezina, K. Makarski i G. Wesołowski. Autorzy, wykorzystując model DSGE, przedstawili sytuację polskiej gospodarki, gdyby w Polsce przyjęto euro z początkiem $2007 \mathrm{r}$. Wykazali, że efektem byłaby niższa minimalna i wyższa maksymalna stopa wzrostu PKB - przedział wahań wyniósłby od $-6 \%$ do $+9 \%$, podczas gdy faktyczny przedział wahań wyniósł od $+1 \%$ do $+7 \%{ }^{20}$.

${ }^{20}$ M. Brzoza-Brzezina, K. Makarski, G. Wesołowski, Would it have paid to be in the eurozone?, „Economic Modelling” 2014, No 41, s. 66-79. 


\section{Podsumowanie}

Między rokiem 2007 a 2015 walutę euro przyjęło pięć państw Europy Środkowo-Wschodniej, kolejno: Słowenia, Słowacja, Estonia, Łotwa i Litwa. Skutki tego kroku w tych krajach powinny być istotną wskazówką dla oceny korzyści i kosztów ewentualnego przyjęcia wspólnej europejskiej waluty przez Polskę. W artykule sprawdzono, czy doświadczenia państw EŚW, które przyjęły euro, potwierdzają występowanie trzech zjawisk w literaturze przedstawianych jako potencjalne negatywne skutki przyjęcia wspólnej waluty: wzrost inflacji, spadek konkurencyjności oraz większa zmienność koniunktury.

Analiza kształtowania się stopy inflacji nie potwierdza istnienia efektu wzrostu cen w związku z konwersją waluty w państwach EŚW, które przyjęły euro. W części państw obserwowano wzrost inflacji oraz wzrost różnicy wobec inflacji obserwowanej w strefie euro (dotyczy to zwłaszcza Słowenii oraz w mniejszej skali Łotwy), jednak w części państw - na Słowacji oraz Litwie - wskaźnik cen odchylał się w dół. Badania wskazują, że wzrost cen w wyniku konwersji waluty, jeśli występuje, to jest niewielki i jednorazowy. Konwersja waluty ma natomiast wpływ na wzrost luki między percepcją inflacji wśród konsumentów a jej faktycznym poziomem, choć efekt ten także jest przejściowy.

Dane dla państw EŚW nie dają także podstaw do twierdzenia, że przyjęcie euro wiąże się z trwałym pogorszeniem międzynarodowej konkurencyjności. Spadek konkurencyjności wobec największej gospodarki UE - Niemiec - nastąpił we wszystkich państwach EŚW (tzn. wzrost jednostkowych kosztów pracy był wyższy niż w tym kraju). Skala tego spadku była jednak różna. Co istotne, w gronie państw o relatywnie wysokim wzroście jednostkowych kosztów pracy znajdują się zarówno kraje, które stosowały sztywne powiązanie własnej waluty z euro i przyjęły euro, jak i kraje, które stosowały kurs płynny. Podobnie w gronie państw o umiarkowanym wzroście jednostkowych kosztów pracy. Państwa EŚW, które przyjęly walutę euro, nie odnotowały także pogorszenia bilansu handlu zagranicznego. Wręcz przeciwnie, wszystkie poprawiły saldo handlu zagranicznego wobec $2004 \mathrm{r}$.

Porównanie stóp wzrostu PKB w państwach EŚW, które przyjęły euro, oraz w wybranych państwach EŚW, które mają własną walutę, potwierdza natomiast, że te kraje, które przyjęły wspólną europejską walutę, charakteryzują się większą amplitudą wahań koniunktury (przy podobnej średniej stopie wzrostu PKB). Dotyczy to zwłaszcza państw bałtyckich, w których różnica między minimalną a maksymalną stopą wzrostu PKB w latach 2004-2018 wyniosła ok. 25 pkt proc. Z kolei trzy państwa o relatywnie niskiej rozpiętości stopy wzrostu PKB w badanym okresie to Czechy, Polska i Węgry, a więc kraje mające własną walutę.

Na tej podstawie można przewidywać, że prawdopodobnym scenariuszem w razie przyjęcia przez Polskę euro byłoby: 
- brak wzrostu lub niewielki i jednorazowy wzrost cen w wyniku konwersji waluty oraz przejściowy wzrost luki między percepcją inflacji wśród konsumentów a jej faktycznym poziomem,

- brak utraty międzynarodowej konkurencyjności i pogorszenia się salda handlu zagranicznego będący rezultatem przyjęcia wspólnej europejskiej waluty,

- większa amplituda wahań koniunktury - niższa minimalna i wyższa maksymalna osiągana stopa wzrostu PKB.

\section{Bibliografia}

Arestis P., Sawyer M., The Design Faults of the Economic and Monetary Union, „Journal of Contemporary European Studies” 2011, No 19(1), https://doi.org/10.1080/1478 2804.2011.554191.

Boratyński J., Borowski J., Czerniak A., Rosati D., Sectoral Decomposition of the Balassa-Samuelson Effect in CEE Countries: A CGE Analysis, „Eastern European Economics” 2019, No 57(2), https://doi.org/10.1080/00128775.2018.1552521.

Brzoza-Brzezina M., Makarski K., Wesołowski G., Would it have paid to be in the eurozone?, „Economic Modelling” 2014, No 41, https://doi.org/10.1016/j.econmod.2014.04.006.

Czerniak A., Smoleńska A., Polska bez euro. Bilans kosztów i korzyści, Polityka Insight, 2019, https://www.politykainsight.pl/en/_resource/multimedium/20164985.

Furceri D., Karras G., Business-cycle synchronization in the EMU, „Applied Economics” 2008, No 40(12), https://doi.org/10.1080/00036840600843954.

Gros D., Macroeconomic Imbalances in the Euro Area: Symptom or cause of the crisis?, „CEPS Policy Brief” 2012, No. 266.

Introduction of the euro in the Member States that have not yet adopted the common currency, European Commission, Flash Eurobarometer 465, Brussels 2018.

Jurek M., Systemy kursów walutowych krajów Europy Środkowo-Wschodniej oraz zmienność kursów ich walut względem euro, „Ekonomista” 2013, nr 2.

Kata R. i in., Strefa euro: między sceptycyzmem a realizmem, Wydawnictwo CeDeWu, Warszawa 2015.

Kawalec S., Pytlarczyk E., Paradoks euro. Jak wyjść z pułapki wspólnej waluty?, Poltext, Warszawa 2016.

Konopczak K., Welfe A., Convergence-driven inflation and the channels of its absorption, „Journal of Policy Modeling” 2017, No 39, https://doi.org/10.1016/j.jpolmod.2017.02.001.

Moons, C., Van Poeck A., Does one size fit all? A Taylor-rule based analysis of monetary policy for current and future EMU members, „Applied Economics” 2008, No 40(2), https://doi.org/10.1080/00036840600749763.

Pufnik A., Effects of the Adoption of the Euro on Consumer Prices and Inflation Perceptions: An Overview of Experiences and Assessment of the Possible Impact in Croatia, Croatian National Bank, Zagreb 2017. 
Rozkrut M., Jakubik J.T., Konopczak K., Efekty zaokragleń cen w Polsce po wprowadzeniu euro do obiegu gotówkowego, „Bank i Kredyt” 2009, nr 40(2).

Sporek T., Perspektywy i konsekwencje wprowadzenia euro w Polsce - bilans korzyści i kosztów, „Zeszyty Naukowe Uniwersytetu Ekonomicznego w Katowicach” 2015, nr 228.

Twarowska K., Ocena polityki kursu walutowego wybranych krajów Europy Środkowo-Wschodniej w aspekcie optymalizacji strategii przyjęcia euro, „Finanse, Rynki Finansowe, Ubezpieczenia" 2016, nr 3(81).

\section{Akty prawne}

Traktat o funkcjonowaniu Unii Europejskiej, Dz.Urz. UE C 326/47 z 26 października $2012 \mathrm{r}$. 